\title{
Food Security Measures and Labor Regulations in the EU-MERCOSUR Agreement: An Overview of the Legal Challenges
}

\section{Medidas de seguridad alimentaria y regulaciones laborales en el Acuerdo UE-MERCOSUR: una visión general de los desafíos legales}

\author{
Mauro Pucheta* \\ César Álvarez Alonso** \\ Carlos Ruiz ${ }^{* * *}$
}

\begin{abstract}
In June 2019, the European Union and MERCOSUR reached a political agreement in order to sign a comprehensive free trade agreement (FTA), which aims to increase interregional trade and to further develop cooperation in noncommercial areas, such as food security and labor regulations. The EU has a normative power through which it intends to export its values and standards. Upon the ratification of this agreement, MERCOSUR and its Member States will certainly need to reform their legal orders so as to align themselves with the food security international standards such as the International Union for the Protection of New Plant Varieties. It may also have an impact upon intellectual property regulations. Labor standards constitute another key aspect of the non-commercial interests of this agreement. In order to avoid social dumping, the EU may require MERCOSUR Member States to ratify ILO Conventions such as the 87 - which has not been ratified by Brazil yet - in order to guarantee a level playing field. Since the final text is currently being discussed, the impact of this agreement will largely depend upon the political will of both parties.
\end{abstract}

Resumen: En junio de 2019, la Unión Europea y MERCOSUR acordaron firmar un acuerdo integral de libre comercio (TLC). Su objetivo es aumentar

* Kingston University London, UK.

** IE University, Spain.

*** Inter-American Institute for Cooperation on Agriculture, Costa Rica.

E-mail: m.pucheta@kingston.ac.uk

Recibido: 29/05/2020. Aceptado: 11/08/2020.

Artículo de acceso abierto. Licencia Creative Commons 4.0. 
el comercio interregional y desarrollar aún más la cooperación en áreas no comerciales tales como la seguridad alimentaria y la normativa laboral. La UE dispone de un poder normativo a través del cual aspira a exportar sus valores y estándares al resto del planeta. Por consiguiente, tras la ratificación de este acuerdo, MERCOSUR y, por ende, sus Estados miembros se verán obligados a reformar sus ordenamientos jurídicos. La seguridad alimentaria puede llevar a los Estados miembros del MERCOSUR a alinearse con la normativa internacional de la materia como aquélla relativa a la Unión Internacional para la Protección de las Obtenciones Vegetales (UPOV). Asimismo, puede tener un impacto sobre la regulación concerniente a la propiedad intelectual. La normativa laboral constituye otro aspecto clave de los intereses no comerciales de este acuerdo. Para evitar el"dumping social", la UE puede exigir a los Estados miembros del MERCOSUR que adopten determinados convenios de la OIT tales como el 87 - que aún no ha sido adoptado por Brasil - para garantizar igualdad de condiciones. Dado que el texto final se encuentra actualmente sometido a negociación, el impacto de este acuerdo dependerá en gran medida de la voluntad política de las partes.

Keywords: European Union, MERCOSUR, food fecurity, labor regulations, Free Trade Agreement (FTA).

Palabras clave: Unión Europea, MERCOSUR, seguridad alimentaria, normativa laboral, acuerdo de libre comercio (ALC).

\section{INTRODUCTION}

In June 2019, the European Union (EU) and MERCOSUR reached a political agreement (henceforth "Agreement") in order to sign a comprehensive free trade agreement (FTA $)^{1}$. This dates back to 1992 when MERCOSUR and the then European Communities signed an Interregional Framework Cooperation Agreement that aimed at strengthening trade between both regions in order to guarantee the competitive integration of MERCOSUR into the world economy and the consolidation of the EU presence in the region ${ }^{2}$. Specifically, relying upon the EU's experience in regional integration, it intended to strengthen the institutional dimension of MERCOSUR. Subsequently, there were multiple bilateral contacts to further cooperation and dialogue that made it possible to establish a lasting relationship between the two blocs.

This was followed by the 1995 Interregional Framework Cooperation Agreement between the European Community and its Member States and MERCOSUR and its Member States in order to increase interregional trade

1 New EU-MERCOSUR trade agreement. The agreement in principle. Brussels, 1 July 2019, see: <https://trade.ec.europa.eu/doclib/docs/2019/june/tradoc_157964.pdf>

2 EUROPEAN COMMISSION. Relaciones Unión Europea-MERCOSUR: Antecedentes. Available at: <https://ec.europa.eu/commission/presscorner/detail/es/MEMO_95_168> 
and further develop cooperation in other areas. It also aimed to develop the political dialogue and the institutional development of MERCOSUR ${ }^{3}$.

The MERCOSUR integration process was supported by the EU from the very beginning. One of the first movements in this regard was the signing of an inter-institutional cooperation agreement in 1992.

Both the EU and MERCOSUR, in addition to being two of the leading regions in agricultural production and trade, also have extensive experience in the mutual exchange of goods, services, investment and cooperation. The relevance of the Agreement is crucial due to several aspects: its size, thematic scope, and political significance. It includes commitments on trade, cooperation, and political dialogue and creates a market of 778 million inhabitants ${ }^{4}$.

The interests of MERCOSUR focus on the opportunity to improve its position in the international scene and to have access to the EU market, whilst the main objective of the EU is to gain access to other markets and to boost its economy. In addition, the weight of the European bloc foreign direct investment (FDI) on MERCOSUR as well as the preferential access of the EU to a market of more than 295 million people are crucial elements that push both parties to sign a legally binding agreement ${ }^{5}$.

Today, the EU is one of the biggest investment and trading partners of MERCOSUR with a cumulative investment stock in the region that has gone from $€ 130$ billion in 2000 to $€ 381$ billion in 2017. MERCOSUR's exports to the EU were $€ 35,9$ billion in 2019 , mainly in agricultural products such as food, beverages and tobacco $(21,2 \%)$, plant products like soy and coffee $(17,4 \%)$, and meat and other animal products (6,5\%). Exports of services to the EU amounted to $€ 10$ billion in $2018^{6}$. EU exports in goods to the four MERCOSUR countries totaled $€ 41$ billion in 2019: machinery $(28,6 \%)$, transport equipment $(12,7 \%)$, chemical and pharmaceutical products $(24,2 \%)$. As for the services sector, the EU exported $€ 21$ billion of services to the Latin American bloc ${ }^{7}$.

The EU has signed FTAs with different countries and regional organizations across the world - such as Switzerland (1972), Norway (1992), Mexico (1997), Chile (2002), and Japan (2018). The Agreement is timely as it was reached against a backdrop of increasing deterioration in multilateralism due to the growing importance of protectionism measures ${ }^{8}$. In 2018, almost

3 Interregional Framework Cooperation Agreement between the European Community and Mercosur, 15 Dec. 1995 - Joint Declaration on political dialogue between the European Union and Mercosur, IO L 69, 19 Mar. 1996.

4 DE AZEVEDO, Belisario et al. "Acuerdo de Asociación Mercosur-Unión Europea". In Instituto para la Integración de América Latina y el Caribe Sector de Integración y Comercio. Banco Interamericano de Desarrollo, 2019, Nota Técnica, no IDB-TN-01701, p. 3.

5 MERCOSUR. En pocas palabras. Available at: <https://www.mercosur.int/quienes-somos/ en-pocas-palabras/>

6 EUROPEAN COMMISSION. Mercosur. Available at: <https://ec.europa.eu/trade/policy/ countries-and-regions/regions/mercosur/>

7 Idem.

8 TIMINI, Jacopo et al. "The EU-Mercosur Free Trade Agreement: Main Features and Economic Impact". Banco de España, Eurosistema. Analytical articles. Economic Bulletin. 2020, n 1, p. 1. 
a third of trade between Europe and the rest of the world was covered by the preferential provisions of an FTA. This figure is expected to increase significantly in 2020, following the entry into force of the agreement with Vietnam, and to rise in the coming years to more than $40 \%$ if the agreement currently being negotiated with MERCOSUR and the United Kingdom comes into force. However, the COVID-19 crisis may constitute a significant challenge.

Originally, FTAs sought exclusively to further increase trade. However, since the 1990s and particularly the 2000s, the EU has also pursued objectives other than trade, such as political, social, and cultural goals. The EU does not only aim to expand its markets: it has a normative power through which it intends to export its values and standards to other countries. The EU has excelled in employing soft power policies, attracting allies through European values, such as democracy and human rights. This paper focuses on some of the non-commercial interests of the Agreement and particularly on two specific areas: food security and labor.

Food security is a sensitive area as MERCOSUR constitutes one of the biggest producers and exporters of food in the world. This has created some internal conflicts within the EU because some agricultural countries, such as France, Poland, and Ireland, have called into question this Agreement given the possible unfair competition. It has been argued that MERCOSUR Member States may not comply with certain measures related to Sanitary and Phytosanitary (SPS), which could lower their costs of food production and could put EU consumers at risk. SPS measures are strongly linked to the trade dimension, since in many cases they represent Technical Barriers to Trade (TBT) by which counterparties to international agreements seek subterfuges. However, by their nature, they also aim to ensure food security within countries and to ultimately protect citizens' health. This article addresses specifically the non-commercial aspect of food security and the legal challenges that the adoption of the Agreement may entail.

Another crucial area in this non-commercial dimension is labor rights. It is well-known that cheap labor is sometimes used as a way to improve the competitiveness of countries by reducing labor standards. This is all the more the case when one party, such as some EU countries, may be more competitive due to technology and a highly skilled labor force. This may push some MERCOSUR Member States to reduce the cost of production by making labor cheaper through the reform in pejus of labor standards. Unsurprisingly, a 'Trade and Sustainable Development' chapter has been included in the Agreement, which aims to guarantee, inter alia, fundamental labor rights within both organizations.

A caveat is in order: given the fact that this is not the final agreement, there are many details that remain to be discussed and agreed between the parties. However, this is not an obstacle to examine the existing provisions enshrined in the political agreement and their possible impact and consequences in the event of a definitive signature of an FTA. 
This paper starts off by exploring the nature, structure, and content of the Agreement. It then explores the concept of food safety and the possible implications for the EU and particularly for the MERCOSUR Member States. Furthermore, this article examines how the Trade and Sustainable Development Chapter may contribute to reshape labor regulations within MERCOSUR and its Member States legal orders.

\section{THE EU-MERCOSUR AGREEMENT WITHIN THE DIVERSE REGIONAL EXTERNAL POLICIES}

\subsection{EU and MERCOSUR External Policies}

The relationship between the EU and Latin America has been built and developed over decades. Unsurprisingly, different types of bilateral and multilateral agreements have been reached between the EU and Latin American countries. The EU and Mercosur have signed a 'new generation' (or fourth generation) agreement ${ }^{9}$, which covers topics that go beyond purely traditional trade issues. These FTAs incorporate political dialogue and cooperation and include new areas such as intellectual property, science and technology, environmental and labor matters. This is related to the socalled 'Global Europe' trade strategy that explicitly mentions that FTAs can go "further and faster in promoting openness and integration, by tackling issues which are not ready for multilateral discussion"10. The EU not only develops relations between its Member States at a legal level, but also stands as a true subject of international law, with clear foreign policy implications. Its regulatory power transcends internal effects and is projected on other blocs and regions with which FTAs are negotiated, with first-order legal consequences.

The EU signs agreements in order to grow and expand its economy and power by accessing third countries' markets. Similarly, third countries, such as MERCOSUR Member States, aim to have access to the EU market. The EU's power is not only limited to trade: the EU has a vocation to promote global human rights and, thus, to create a global regulatory framework, which includes a social perspective ${ }^{11}$. It also aims to level the playing field and make sure EU firms are not confronted with competitors who do not respect the same standards, such as the ILO ones ${ }^{12}$.

Sanahuja and Rodríguez identifies the EU as an "external federator"13.

9 GSTOHL, Sieglinde and HANF, Dominik. "The EU 's Post-Lisbon Free Trade Agreements: Commercial Interests in a Changing Constitutional Context". European Law Journal. 2014, vol 20, $n^{\circ}$ 6, p. 733-735.

10 Available at: <https://www.consilium.europa.eu/en/eu-free-trade/>

11 NOVITZ, Tonia. "In Search of a Coherent Social Policy: EU Import and Export of ILO Labour Standards?". In ORBIE, Jan and TORTELL, Lisa (Eds.). The European Union and the Social Dimension of Globalization. London: Routledge, 2009.

12 CAMPLING, Liam et al. "Working Beyond the Border? A New Research Agenda for the Evaluation of Labour Standards in EU Trade Agreements". International Labour Review. 2015, p. 6-7.

13 SANAHUJA, José Antonio and RODRIGUEZ, Jorge. "Veinte años de negociaciones Unión 
This means that the EU acts as a real mentor and provides technical and institutional capacities to other countries with which it intends to sign agreements in order to face the challenges of international trade. Furthermore, it attempts to support regional integration processes such as MERCOSUR, which comply with characteristics similar to those of the EU integration process. The power relationship between the EU and its partners will depend upon the context and will be immersed in a situation of interdependence of the parties, which will be asymmetric ${ }^{14}$.

According to the Treaty of Lisbon, all matters related to the EU Common Commercial Policy are included into the sphere of exclusive competence. The Treaty defined the Common Trade Policy in the context of the Union's external action (Article 207 Treaty on the Functioning of the European Union). In addition, article 206 reminds us of the contribution of the EU to "the harmonious development of world trade, the progressive abolition of restrictions on international trade and on foreign direct investment, and the lowering of customs and other barriers". Article 21 TEU reinforces this dimension as it states that "the Union's action on the international scene shall be guided by the principles which have inspired its own creation, development and enlargement, and which it seeks to advance in the wider world: democracy, the rule of law, the universality and indivisibility of human rights and fundamental freedoms, respect for human dignity, the principles of equality and solidarity, and respect for the principles of the United Nations Charter and international law".

The EU external dimension is of utmost importance, especially its foreign policy. Other trade blocs also encourage common external action, such as ASEAN, which in its Vision 2025 has the objective to become "an outward-looking community" that "plays a responsible and constructive role globally"15. In this new generation of agreements, such as the EU-Mercosur agreement, negotiators must not only focus on eliminating potential barriers to trade: it is their task to "facilitate harmonisation of the rules in question and hence extend and prolong the advantages achieved as a result of the negotiation" ${ }^{\prime 16}$.

Unlike the EU, which looks both inwards and outwards, external

Europea-Mercosur: Del interregionalismo a la crisis de la globalización". Fundación Carolina. 2019. Available at: <https://www.fundacioncarolina.es/wp-content/uploads/2019/09/DT_ FC_13.pdf>

14 SANAHUJA, José Antonio. “¿Un mundo unipolar, multipolar o apolar? El poder estructural y las transformaciones de la sociedad internacional contemporánea". In: VV AA (Eds). Cursos de Derecho Internacional de Vitoria-Gasteiz 2007. Bilbao: Servicio Editorial de la Universidad del País Vasco, 2008. p. 297-384. Available at: <https://eprints.ucm.es/42540/1/Un_mundo_ unipolar_multipolar_o_apolar_E.pdf>

15 MERCED, Louie Dane C. "'Partners' for Change: Understanding the External Relations of ASEAN". Center for International Relations and Strategic Studies Commentaries. 2017, vol 4, $\mathrm{n}^{\circ} 20$, p.2

16 BENDINI, Roberto. "The Future of the EU Trade Policy". Policy Department. European Parliament, 2015, p. 15. 
markets have a significant importance for Mercosur Member States ${ }^{17}$. The institutional structure of the MERCOSUR external dimension is rather weak. The Treaty of Asunción prescribes that MERCOSUR Member States aim to adopt a common trade policy for MERCOSUR. This has been confirmed by the Council of the Common Market - the highest body of MERCOSUR - Decision No 32/00, which sets out that Member States commit themselves to negotiate and sign FTAs jointly. Although MERCOSUR's development throughout 28 years has been unsteady and incoherent, some trade agreements have been signed not just with Latin American countries but also with Asian and African countries, as well as other regional organizations ${ }^{18}$. Furthermore, there are ongoing negotiations with Canada, Korea, and China, among others. Even though there have been some very recent conflicts regarding the external dimension of MERCOSUR - in particular given the position of the Argentine government - the EU-MERCOSUR agreement has never been called into question and Member States wish to push it forward".

From a Latin American perspective, initially FTAs were considered as "imperialist" tools used either by the United States or the EU to mainly protect their (economic) interests ${ }^{19}$. However, as regional integration processes developed, Latin American trade organizations became aware of the importance of economic integration with other blocs in order to boost the regional economy. This awareness, though, has not been traditionally applied to the FTAs signed by Latin American organizations, in particular MERCOSUR. They remain "first generation trade agreements, and none of them contains explicit clauses of democratic or human rights safeguards" 20 . Nonetheless, this new approach has shaped the internal dimension of Latin America regional organizations, whose openness to human rights has been mainly caused by the pressure exerted by outside actors ${ }^{21}$.

\subsection{The EU-MERCOSUR Relationship}

The EU-MERCOSUR relationship dates back to 1992. MERCOSUR Member States have not only historical but also cultural and linguistic ties with some countries of the EU ${ }^{22}$. The primary goal of the 1992 Agreement

17 MUKHAMETDINOV, Mikhail. Mercosur and the European Union. Variation and Limits of Regional Integration. Cambridge, MA: Palgrave Macmillan, 2019, p. 48.

18 Mercosur has signed, or is still negotiating, agreements with other economic blocs such as CAN, SACU, the Cooperation Council for the Arab States of the Gulf, the CARICOM, the ASEAN, the Australia-New Zealand Closer Economic Relationship Treaty Agreement, the Community of Portuguese Language Countries (CPLP), and the Central American Integration System (SICA). Mercosur is also currently negotiating with EFTA, with which a Declaration on Trade and Investment Cooperation and Action Plan was signed. In addition, Mercosur has signed some agreements with individual countries such as Chile, Bolivia, Mexico, Cuba, India, Egypt, Morocco, Israel, Pakistan, and Colombia.

19 FRANCA FILHO, Toscano et al. "Protection of Fundamental Rights in Latin America FTAs and Mercosur: An Explanatory Agenda". European Law Journal. 2014, vol 20, n²0(6), p. 811-815.

20 Idem, 822.

21 Idem, 822.

22 FRANCA FILHO, Toscano. "External Relations". In: FRANCA FILHO, Toscano et al. (Eds.) The 
was the provision of technical and institutional support. However, it is the ambitious interregional Framework Cooperation Agreement signed on 15 December $1995^{23}$, which entered into force on 1 July 1999, which has laid the formal foundations of this relationship ${ }^{24}$. This Agreement constitutes an "obligation of means, by which the parties look forward to preparing the conditions for enabling the interregional free trade area to be created" 25 . Three main areas are to be addressed by the future FTA: trade, political dialogue, and cooperation.

The commercial sphere remains the main objective of this Agreement. However, it has broadened its horizons by incorporating a strategic political and economic association that aims for greater regional integration, not only between the EU and MERCOSUR, but also between the Member States of the latter through the application of common policies for the production, importation, and exportation of products. The Agreement recently agreed and signed by the parties, if ratified, would become one of the most ambitious agreements reached to date by both blocs. There is still a long legal and administrative process to go through before final approval ${ }^{26}$. There are some sectors that oppose the Agreement, such as the agricultural sector in the EU and the industrial and automobile sector in MERCOSUR ${ }^{27}$. However, given the positive economic impact that the signature of the Agreement could entail, there are many actors that overtly advocate adopting it.

The EU-MERCOSUR Agreement revolves around three axes: firstly, trade and the gradual and progressive liberalization of access to markets. Given the fact that MERCOSUR Member States are some of the biggest exporters of food, one of the key aspects of this Agreement is SPS matters. Secondly, cooperation has been crucial for the institutional development of MERCOSUR as well as the strengthening of certain areas such as labor rights. Thirdly, given the period of dictatorships during the 1970s and 1980s, political dialogue has been crucial to consolidate democracy in the region. MERCOSUR, through the Protocol of Ushuaia I (1998) and the Protocol of Ushuaia II (2005), has created and reinforced the "democratic clause", which guarantees the respect of democracies in the region by its Member States. This has been done under the auspices of the EU and has been applied when coups d'état took place in Paraguay in 2013 and in Venezuela in 2017.

Law of MERCOSUR. Oxford: Hart Publishing, 2010, p. 151.

23 See footnote 5 .

24 Decision 1999/279/EC concerning the conclusion of the interregional framework cooperation agreement between the European Community and its Member States, and the Southern Common Market and its Party States, IO L/112.

25 FRANCA FILHO, Toscano. "External Relations", p. 153.

26 EUROPEAN COMMISSION. EU and Mercosur reach agreement on trade. Available at: <https://ec.europa.eu/commission/presscorner/detail/en/IP_19_3396>

27 "Acuerdo Mercosur-UE: quiénes son los ganadores y los perdedores del nuevo pacto comercial". BBC. July 1, 2019. Available at: <https://www.bbc.com/mundo/noticias-americalatina-48833560> 


\section{FOOD SECURITY}

\subsection{Food Security and Food Safety}

Food security is globally one of the main challenges. Globalization has allowed synergies and has developed tools to achieve greater access to goods and services. However, it has worsened many of the endemic problems caused by market liberalization, such as inequality and food insecurity. In 2018, the UN Secretary-General, António Guterres, affirmed that "the increase in inequality has become the face of globalization" and it is necessary "a world economy that benefits all and creates opportunities for everyone. We need to build a fair globalization" 28 .

Food security also plays a central role in the development and wellbeing of the population, especially in the most vulnerable settings. The 2030 Agenda of the United Nations (UN) in its Sustainable Development Goals (SDGs), specifically in SDG 2, includes this. Focused on the development of agriculture as an engine of development and the elimination of hunger and poverty, this SDG aims to ensure people's access to and availability of nutritious food and to ensure new forms of agricultural productivity that improve food security globally, through sustainable and environmentally friendly methods ${ }^{29}$.

This article relies upon the definition of food security adopted at the World Food Summit held in Rome in 1996: "Food security exists when all people, at all times, have physical and economic access to sufficient safe and nutritious food that meets their dietary needs and food preferences for an active and healthy life" ${ }^{30}$. This definition has introduced four dimensions of food security: physical availability, when people can have food through production or trade; economic and physical access, understanding that food security is not only achieved through a sufficient supply of food; utilization, consumption and preparation of diverse food, combined with good biological utilization, that allow for a healthy life; and stability over time of the other 3 dimensions. Food security cannot be achieved if the 3 dimensions are not stable over time and suffer variations (weather conditions, unemployment, or political instability) ${ }^{31}$. A large part of the concept of food safety is also included under this definition. This concept is mainly used to describe the SPS measures. Since this term encompasses many facets of handling, preparation, and storage of food to prevent illness and injury, it is closely related to food security.

This can be traced back to the 1995 Interregional Framework Agreement, where the bases for future negotiations were set out. More

28 UNITED NATIONS. El aumento de la desigualdad, el rostro de la globalización. Available at: <https://news.un.org/es/story/2018/05/1433082>

29 UNITED NATIONS. Goal 2: Zero Hunger. Available at: <https://www.un.org/ sustainabledevelopment/hunger/>

30 FAO. An Introduction to the Basic Concepts of Food Security [online]. EC - FAO Food Security Programme, 2008. (Information Document). Available at: <http://www.fao.org/3/a-al936e.pdf > 31 Idem. 
specifically, Article 6 provides that both parties intend to cooperate in promoting the closeness of quality standards for agri-food products, industrial goods, and certification, in accordance with international criteria. This article also states that "[t]he primary aim of cooperation shall be to promote any measure which is likely to improve the quality of the Parties' products and businesses" ${ }^{\prime \prime 2}$.

The texts of the Agreement, in principle only refer to food safety; however, food security is a wider definition. This concept should cover SPS measures but also many of the problems associated with the liberalization of markets due to the signature of agreements. These issues result, in many cases, in food insecurity, not only because of the overuse of pesticides and chemicals but also because of the effects they cause on local communities.

\subsection{Food Security under the EU-MERCOSUR Agreement and its legal framework}

This subsection addresses issues related to how the entry into force of the Agreement can influence food security within the EU and MERCOSUR, and whether it includes mechanisms for identifying and penalizing practices that could result in a breach of it. To do so, policies, regulatory frameworks, initiatives, and commitments oriented to food security are analyzed within the Agreement. There is an assumption that, in the EU, during the first years of the Agreement, the consumer may benefit from lower prices and greater competition in products. However, the opposite may occur in MERCOSUR. This may be due to the adaptation of the supply and demand of products, which would lead the MERCOSUR countries to allocate a greater part of their agricultural production to export and to incorporate new and more rigorous SPS measures, seals and quality certifications and food safety. On the other hand, the liberalization of markets would foster greater interest in the large-scale production of big agricultural companies that exploit the country's resources for the sole purpose of exporting them. In many cases, these companies are foreign, and their land grabbing displaces small farmers with family as well as local and more sustainable production systems, which could reduce food security and nutrition of the most disadvantaged. On the European side, the strict controls required on the products of European farmers would be difficult to trace on all MERCOSUR imports without an effective system in the countries of origin. This can affect the nutritional and healthy qualities of imported food and feed, as well as generate processes of unfair and unequal competition.

\subsubsection{Paving the way}

Although it is clear that food security is covered under the umbrella of the Agreement, food safety is more important for the trade pillar and the overall interests of the EU. This is an asset that has been included in the

32 See footnote 5 . 
negotiations and one of the reasons why the EU has been ensuring strong SPS measures for the import of food products, not only inside its borders, but also beyond them. The EU's 2007-2013 Regional Strategic Document for the MERCOSUR region places greater emphasis on the needs of the European bloc to reinforce aspects necessary for the proper functioning of the future Agreement, which 12 years later, has not been ratified. In this line, it stands out that $70 \%$ of what the EU contributes (48 million euros) goes to "support for the deepening of MERCOSUR and the implementation of the future EUMERCOSUR Association Agreement" ${ }^{\prime \prime 3}$, within which food safety and hygiene is a priority axis. Another key aspect of this strategy is to consolidate the integration of the MERCOSUR countries, as defined in its objectives: "[t]o help accelerate and complete the Integration Work Program of MERCOSUR. To support the seamless implementation of the future EU-MERCOSUR Association Agreement" ${ }^{\prime 34}$. The strategic framework for the European Commission's cooperation with MERCOSUR intends to improve the institutional framework and mechanisms for detection and prevention of SPS, among others. Thus, through these actions, the EU aims to focus the aid provided in the regional strategy to pave the way to improve the present conditions so that the future Agreement between the two blocs is as successful as possible and that it is adapted to the demands of the European bloc.

\subsubsection{Legal Regulations}

Another key area related to food security, also within the scope of the Agreement, are the measures and requirements related to intellectual property. One of the most contentious one, particularly by small farmers and indigenous communities, are those related to the protection and privatization of seeds. These seeds in many cases were acquired through traditional knowledge through the crossing of species between ancestral communities, which today see how large corporations are privatizing them. This is the case of the International Union for the Protection of New Plant Varieties (UPOV). This intergovernmental organization, through its agreements, aims to "[p] rovide and promote an effective system for the protection of new varieties [...] for the granting of an intellectual property right ${ }^{\prime \prime 3}$. In practice, this implies that farmers and indigenous communities of the signatory countries must respect the rules when it comes to the use of seeds. These rules force them to prevent from reusing and exchanging seeds and forcing them to buy new ones in each harvest. Otherwise, the breach may result in penalties as well as

33 EUROPEAN COMMISSION. Documento estratégico regional 2007-2013 [Online]. Brussels: s.n, 2007. (Strategic Document European Commission), p. 5. Available at: <http://eeas.europa. eu/archives/docs/mercosur/rsp/07_13_es.pdf>

34 Idem, p. 34.

35 MINISTERIO DE ASUNTOS EXTERIORES, UNIÓN EUROPEA Y COOPERACIÓN DE ESPAÑA. UPOV. Available at: <http://www.exteriores.gob.es/RepresentacionesPermanentes/ Oficinadelas NacionesUnidas/es/quees $2 / P a g i n a s / C o n v e n i o s \% 20 y \% 20$ otras $\% 20$ Organizaciones\%2OInternacionales/UPOV.aspx> 
prison in some cases. In other words, a subsistence farmer who produces for his family and does not buy the seeds in the market and pays the intellectual property fee will face severe legal consequences.

The Agreement in Principle does not lag behind in this context and incorporates in its chapter number 13, "Intellectual and industrial property rights", the duty of the parties to protect the intellectual property rights of plant varieties in accordance with the UPOV 91 agreement. The objective of this measure is to strengthen the national legal framework of the signatory countries in order to penalize some practices by rural communities such as the free use of seeds for their crops. Furthermore, these practices are reinforced by the Agreement through more demanding legal frameworks to identify and punish these cases $^{36}$. For instance, one of the reasons for delaying the entry into force of the EU-CAAA (the European Union Central American Association Agreement) agreement, signed in 2012, was due to geographical indications $(\mathrm{GIs})^{37}$. This clause is included within the chapter on intellectual property and results in an obligation for the parties to respect the designations of origin of the countries. Parties must introduce in their domestic legislation measures that regulate the use of names registered with the designation of origin. This has led to serious consequences in the commercialization of products in Central America after the approval of the agreement. Products that were previously marketed under names like Mozzarella or Manchego, must change their names ${ }^{38}$. In the case of the EU-MERCOSUR Agreement, there are a total of 355 products protected by a European GI, while the EU will safeguard a total of $220 \mathrm{Gls}$ from MERCOSUR ${ }^{39}$. In addition, expressions such as "type", "style", "imitation" or the like will also be prohibited. For example, "Chaco type meat" 40 .

Another element that undermines the sovereignty of countries is the ability of trade and association agreements to complement and shape the legal power of countries and establish new rules that benefit the market and protect commercial interests. In Chapter 4 of the principle agreement entitled "Trade defense instruments", it is mandatory that if any of the parties intends to impose safeguard measures, the party will endeavor to impose them in a way that affects bilateral trade the least ${ }^{41}$. Countries must be respectful

36 EUROPEAN COMMISSION. Intellectual Property Chapter [online]. Brussels: s.n, 2019. (Texts of the Trade Part of the EU-Mercosur Association Agreement). Available at: <https://trade. ec.europa.eu/doclib/docs/2019/september/tradoc_158329.pdf>

37 SICE. Acuerdo de Asociación Centroamérica-Unión Europea. Available at: <http://www.sice. oas.org/Trade/CACM_EU/Text_Sept14/Index_s.asp>

38 "Crónica de un queso: su camino a ser denominación de origen y retos a enfrentar". Mercosur. 2019. Available at: <http://www.marcasur.com/noticia. php?NoNold=5021>

39 EUROPEAN COMMISSION. Annex 1, Legislation of the parties [online]. Brussels: s.n, 2019. (Annex for the Texts of the Trade Part of the EU-Mercosur Association Agreement). Available at: <https://trade.ec.europa.eu/doclib/docs/2019/september/tradoc_158330.pdf>

40 EUROPEAN COMMISSION. Intellectual Property Chapter [online]. Brussels: s.n, 2019. (Texts of the Trade Part of the EU-Mercosur Association Agreement). Available at: <https://trade. ec.europa.eu/doclib/docs/2019/september/tradoc_158329.pdf>

41 EUROPEAN COMMISSION. Trade defense and global safeguards [online]. Brussels: s.n, 2019. 
of bilateral trade, prioritizing commercial interests over the interests of the governments. This is reinforced in the chapter on bilateral safeguard measures where it is established that, if it is finally concluded that there was no such damage, any economic measure imposed must be immediately reimbursed ${ }^{42}$. All these measures aim to provide security to private sector investments, which are mainly promoted by large companies and where the figure of the smallest and most vulnerable sectors is neglected.

In this Agreement, the parties have been interested in negotiating for control over food producers and handlers in order to ensure the adoption of sufficient requirements and standards along with a strong institutionalization that is capable of implementing them. As a result, food security has been relegated to trade facilitation so that sanitary and phytosanitary measures are respected, also to the inclusion of clauses and regulations that respect measures or requirements imposed by the international trade framework. These actions are only aimed at protecting the health of consumers, especially Europeans, by requiring MERCOSUR countries to comply with the high standards of food safety and health that the EU imposes on imports. This is directly related only to one of the dimensions of the food security according to the Food and Agriculture Organization of the United Nations (FAO), which is the dimension of food utilization, however, in a less subtle and more collateral way, the agreement in principle establishes norms and requirements that may affect the 4 dimensions of food security of the signatory countries. This is the case of the rules on intellectual property compliance and the UPOV 91 agreement, which can force rural communities with traditional production methods to pay for seeds that they will not be able to reuse or exchange in future harvests. However, the official content of the cooperation and political pillars remains to be known where this issue should be addressed in greater depth and in all its dimensions.

By way of conclusion, the liberalization of markets and globalization lead to drastic changes to which the most vulnerable populations are not able to adapt with the same ease as the large economies and their defense mechanisms. In addition, some clauses included in the agreements, as in the one outlined here, undermine the sovereignty of countries by adding obligations and clauses to national regulations. These changes and obligations cause mismatches that can lead to weakening the food security. In addition, the global food system fed by this new reality, causes the problems with food security that were previously focused and had a reduced field of affectation, now become international priorities with global effects.

(Texts of the Trade Part of the EU-Mercosur Association Agreement). Available at: <https:// trade.ec.europa.eu/doclib/docs/2019/july/tradoc_158157.\%20Trade\%20Defense\%20-\%20 General\%20Principles\%20and\%20Global\%20Safeguards.pdf>

42 EUROPEAN COMMISSION. Bilateral safeguard measures [online]. Brussels: s.n, 2019. (Texts of the Trade Part of the EU-Mercosur Association Agreement). Available at: <https:// trade.ec.europa.eu/doclib/docs/2019/july/tradoc_158158.\%20Trade\%20Defense\%20-\%20 Bilateral\%20Safeguards.pdf> 


\section{LABOR REGULATIONS}

\subsection{EU-MERCOSUR Labor Provisions}

Labor rights were not considered in the first EU free trade agreements. However, since the late 1990s, there has been a change of approach. In its FTA with South Africa (1999), the EU included for the first time labor standards. From the mid-2000s, this approach has been reinforced and consolidated. The Treaty of Lisbon constitutes a step forward in the promotion of core labor standards through the EU external relations policies ${ }^{43}$. Its agreement with the CARIFORUM (2008) introduced a monitoring process on the application and respect of the core labor standards. All the FTAs concluded afterwards - South Korea (2010), Peru and Colombia (2011) - include core labor standards and a procedure to guarantee their implementation and monitoring ${ }^{44}$.

The Interregional Framework Cooperation Agreement between the then European Community and MERCOSUR (1995), makes explicit references to the protection of fundamental labor rights. Firstly, the third recital sets out that "both integration processes are instruments for the economic and 'social' development". In the same vein, one of the objectives of Article 10.1 is to "establish conditions conducive to job creation and job quality". Even more importantly, Article 10.7 refers to the necessity of the promotion of fundamental social rights. This agreement is not only important because it has been the framework of the negotiations, but also it has contributed to the development of the internal labor dimension of MERCOSUR ${ }^{45}$.

This has been reinforced by the current EU-MERCOSUR political agreement ${ }^{46}$, which - similar to the new generation agreements and influenced by the ILO Declaration on Social Justice for a Fair Globalisation (2018) and the 2030 Agenda for Sustainable Development (2015) - sets out three types of measures ${ }^{47}$. Firstly, the agreement has a substantive dimension, which enshrines some social policy norms and ILO Core Labor Standards (Article 4). Specifically, the agreement relies upon the 1998 ILO Declaration on the Core Labor Standards: Freedom of association and the effective recognition of the right to collective bargaining (ILO Conventions 87 and 98); the elimination of forced labor (ILO Conventions 29 and 105); the abolition of child labor (ILO Conventions 138 and 182); and the elimination of discrimination in respect

43 PERULLI, Adalberto, "Fundamental Social Rights, Market Regulation and EU External Action". International Journal of Comparative Labour Law and Industrial Relations. 2014, vol $30, \mathrm{n}^{\circ} 1$, p. $27,40$.

44 GSTOHL, Sieglinde and HANF, Dominik. Op. cit., p. 742.

45 MANSUETI, Hugo. Derecho del Trabajo en el Mercosur. Buenos Aires: Ciudad Argentina,1999. p. 92; PUCHETA, Mauro. "Regional Integration and Labour Law: A Comparative Analysis of the EU and Mercosur". Orientador: Jeff Kenner. University of Nottingham. Nottingham, 2019.

46 EUROPEAN COMMISSION. Trade and Sustainable Development [online]. Brussels: s.n, 2019. (Texts of the Trade Part of the EU-Mercosur Association Agreement). Available at: <https://trade.ec.europa.eu/doclib/docs/2019/july/tradoc_158166.\%20Trade\%20and\%20 Sustainable\%20Development.pdf>

47 VAN DE PUTTE, Lore and ORBIE, Jan. "EU Bilateral Trade Agreements and the Surprising Rise of Labour Provisions". International Journal of Comparative Labour Law and Industrial Relations. 2015, vol 31, n³, p. 263, 268-269. 
of employment and occupation (ILO Conventions 100 and 111). The EUMERCOSUR agreement has gone further and has included new references to ILO Conventions such as health and safety of workers (ILO Conventions 155 and 7), labor inspection (ILO Conventions 81 and 129), and discrimination against migrants (ILO Convention 143). Furthermore, the agreement prescribes that Parties have an obligation to uphold levels of protection. This means that they cannot lower not de jure or de facto domestic labor law (regulations) in order to enhance their competitiveness (Article 2).

Secondly, procedural norms have been included in order to guarantee their implementation by the parties. There are two general procedures that aim to ensure the implementation of labor provisions. Domestically, a Domestic Advisory Group (DAG) - composed of NGOs, business, trade unions - has been conceived in order to ensure the participation of the local civil society in this process. Transnationally, a Parties' Sub-committee on Trade and Sustainable Development has been created in order to oversee the implementation of this chapter (Article 14). It has also created a joint Civil Society Forum where DAGs and/or other civil society actors can interact. Furthermore, the agreement enshrines two special procedures. As the other generations' agreements that recognize the possibility of governments' representatives to settle issues in an amicable government consultations procedure (Article 16). On top of that, the new generation agreement conceives a Panel of Experts that can issue a non-legally binding final report and recommendations to the Parties, which should implement its conclusions (Article 17). Although it is a step forward, this has been criticized because the EU has adopted a "soft" incentivesbased approach unlike the "hard" sanctions-based approach adopted by the US. ${ }^{48}$ No sanctions can be imposed on the non-compliant party, such as the suspensions of trade preferences against the other party. ${ }^{49}$ The weakness of this enforcement system has undermined the confidence of civil society and other stakeholders such as trade unions ${ }^{50}$. Furthermore, the EU has been reluctant to use the dispute resolution mechanism. This has led to papers from the European Parliament, trade unions, NGOs, and a response of the European Commission in order to overcome these institutional challenges ${ }^{51}$. It has been suggested that a private complaints procedure which would allow social partners to bring complaints, could constitute a desirable solution ${ }^{52}$.

Thirdly, a governance dimension has been created in order to ensure the implementation of labor provisions. On the one hand, some provisions on Corporate Social Responsibility have been enacted in order to encourage

48 Idem, p. 263, 270; HARRISON, James et al. "Labour Standards Provisions in EU Free Trade Agreements: Reflections on the European Commission's Reform Agenda". World Trade Review. 2019 , vol $18, n^{\circ} 4$, p. $635,641$.

49 HARRISON, James et al. "Labour Standards Provisions ...", p, 641.

50 BRONCKERS, Marco and GRUNI, Giovanni. "Taking the Enforcement of Labour Standards in the EU's Free Trade Agreements Seriously". 2019, vol 56, n 6, p. 1591, 1592.

51 See: HARRISON, James. "The Labour Rights Agenda in Free Trade Agreements". Journal of World Investment \& Trade. 2019, $\mathrm{n}^{\circ}$ 20, p. 705, 714, 720-721.

52 See: BRONCKERS, Marco and GRUNI, Giovanni. Op. cit., p. 1591. 
companies to comply with social standards, particularly in the management of supply chains (Article 11). Similarly, civil society actors, such as trade unions and business organizations, can take part in the discussions regarding social issues that may arise under the FTA. Given the rather poor results of the procedural system previously described, cooperation mechanisms can constitute a good device for promoting labor standards ${ }^{53}$. This is all the more the case in MERCOSUR where social partners - particularly in Argentina and Brazil - are key actors in the implementation of labor standards. Criticisms have been pointed out, though, to cooperative mechanisms given the lack of systematic implementation and assessment of cooperative activities ${ }^{54}$. Therefore, it will be critical that both parties ensure that civil society actors play a prominent role in the implementation of the Trade and Sustainable Development Chapter.

\subsection{The Possible Reforms at the MERCOSUR Labor Dimension}

Depending upon the final text and the intention of the parties, the EUMERCOSUR agreement can have a threefold impact upon MERCOSUR and its Member States labor dimension: firstly, it may contribute to enforcement of the Socio-Labor Declaration. Secondly, par ricochet, it could be the legal basis to challenge the current trade union systems of Argentina and Brazil. Thirdly, it may help to reduce informality in the region.

Relying upon a myriad of international human rights instruments and the 1998 ILO Declaration on Fundamental Principles and Rights at Work which enshrines core four fundamental rights: freedom of association and the right to organize and bargain collectively; prohibition of forced labor; eradication of child labor; and, equality of treatment and non-discrimination in employment - MERCOSUR adopted in 1998 the Socio-Labor Declaration, recently revisited in 2015. This instrument protects fundamental labor rights within MERCOSUR and its Member States legal orders. It guarantees the protection of individual labor rights such as non-discrimination (Article 4), equal treatment between men and women and disabled workers (Articles 5 and 6), equal treatment principle of foreign workers with national workers (Article 7), elimination of forced labor (Article 8), child labor (Article 9), working time (Articles 11, 12, 13 and 14), and protection against unfair dismissal (Article 15). It also enshrines collective rights such as freedom of association (Article 16), right to collective bargaining (Article 17), right to strike (Article 18), promotion and development of alternative dispute resolution systems of industrial conflicts (Article 19), social dialogue (Article 20). The Socio-Labor Declaration has undoubtedly been a watershed moment in the MERCOSUR labor dimension ${ }^{55}$. However, given the intergovernmental nature

53 See: EBERT, Franz. "Labour provisions in EU trade agreements: What potential for channelling labour standards-related capacity building?". International Labour Review. 2016, vol 155, n³, p. 407, 412-413.

54 HARRISON, James et al. "Labour Standards Provisions...", p. 645.

55 CASTELLO, Alejandro. "Revisión y Actualización de la Declaración Sociolaboral del 
of MERCOSUR, its implementation has heavily relied upon Member States ${ }^{56}$. In this respect, the EU-MERCOSUR Agreement may reinforce the importance and enforcement of the Socio-Labor Declaration at the regional and national levels. The Sustainable Trade Chapter contains specific provisions regarding fundamental labor rights - that are in line with the content of the Socio-Labor Declaration - which the EU intends to uphold. Specifically, the role of the Socio-Labor Commission, which is in charge of monitoring the enforcement and development of the Socio-Labor Declaration, could be reinforced either through procedural and/or cooperation mechanisms enshrined in the agreement. This remains to be seen, though, depending upon the signature of a free trade agreement and how keen the EU is in enforcing this chapter. In this area, the use of the procedural avenues as well as the cooperation mechanisms will be vital to enforce these fundamental labor rights ${ }^{57}$.

Secondly, the EU-MERCOSUR agreement could be an element of pressure to the reform of the Brazilian trade union system. Brazil has adopted a system of "unicidade sindical" 58 whereby only one trade union can be created in a specific sector in the same territory ${ }^{59}$. This is partially at odds with the principle of freedom of association, guaranteed by the EU-MERCOSUR agreement (Article 4) for two reasons. Firstly, it makes the adoption of a democratic trade union system difficult, given the excessive powers granted to one specific trade union. Secondly, the state enjoys too much power in regulating and registering trade unions' activities ${ }^{60}$. Unsurprisingly, Brazil has not ratified the ILO Convention 87. However, the Socio-Labor Declaration guarantees the protection of freedom of association as well as collective bargaining, and the right to take collective action (Articles 16, 17 and 18), These provisions rely heavily upon the ILO Conventions 87 and 98. Consequently, it has been argued that the current unicidade sindical system has been indirectly modified through the adoption of the Declaration, which is hierarchically superior to ordinary laws ${ }^{61}$. Though, this has not entailed any practical changes. Although it has been argued that the EU may have some insufficient political influence to induce certain policy changes - such as in the Korean case ${ }^{62}$, it could push Brazil to ratify the ILO Convention 87 in order to fully guarantee freedom of association within the biggest trade partner of

\footnotetext{
Mercosur". Derecho Laboral. 2015, n² 260, p. 637, 645.

56 PUCHETA, Mauro, Op.cit.

57 See: EBERT, Franz. Op. cit., p. 407.

58 BRAZIL. 1988 Constitution, Article 8, II.

59 See: GODINHO DELGADO, Mauricio. "Constitución de la República, Sistema Laboral Brasileño y Derecho Colectivo del Trabajo". Derecho Laboral. 2015, no LVII (259) , p. 350.

60 See: FERRAZ HAZAN, Bruno. "A incompatibilidade do modelo a partir da incorporação brasileira dos parâmetros da liberdade sindical". Revista de Direito \& Desenvolvimento da UniCatólica. 2019, vol 2, n 1, p. 26.

61 CASTELLO, Alejandro. Op. cit., p. 647; FERRAZ HAZAN, Bruno. Op. cit., p. 39.

62 HARRISON, James et al. "Governing Labour Standards through Free Trade Agreements: Limits to the European Union's Trade and Sustainable Development Chapters". Journal of Common Market Studies. 2019, vol 57, n², p. 260, 271.
} 
MERCOSUR. As put forward by the European Parliament in the Vietnamese case, this could be done as a "pre-ratification conditionality" in order to ensure the respect of labor standards before the signature of the FTA ${ }^{63}$.

Thirdly, informal work is a structural problem in South America. Argentina and Brazil are not the exception. By the end of 2018, Argentina had $49.3 \%$ of its workforce in the informal economy ${ }^{64}$, while in June of 2019 Brazil had $41.3 \%$ of their workers in the same situation ${ }^{65}$. This is crucial to guarantee the protection of fundamental labor rights. A high number of workers in the informal economy have several negative consequences upon them. Firstly, it facilitates high turnover rates, which has resulted in a 'reserve army of informal workers [that] facilitates quick replacement of laid-off workers'66. This puts pressures on wages and employment conditions, which are diminished ${ }^{67}$. Furthermore, it has had an impact on the training system and the development of the skill regimes. Incentives tend to be much lower in the informal sector ${ }^{68}$. Another negative consequence has been the lack of representation of a significant universe of workers, which are not covered by the existing legal framework ${ }^{69}$. Tackling informal work could also have a positive impact in terms of inequality. Access to welfare benefits is usually tied to formal employment. Therefore, greater protection coverage, as well as the development of a better enforcement system, could also have contributed to the reduction of inequality ${ }^{70}$. ILO has recommended the development of more and better enforcement as well as the development of social dialogue ${ }^{71}$. The development of a professional labor inspectorate is essential to uphold workers' rights as recognized in the ILO Recommendation 205 on the transition from the informal to the formal economy, specifically in section VI ("incentives, compliance and enforcement"). It is possible to see a clear correlation between the strengthening of national labor inspectorates in the region, particularly in Brazil and Uruguay - Argentina to a lesser extent

63 BRONCKERS, Marco and GRUNI, Giovanni. Op. cit., 1596; HARRISON, James et al. "Labour Standards Provisions...", p. 650.

64 CASTELLO, Eduardo, "Heterogeneidad y Fragmentación del Mercado de Trabajo (20102018)". Informe, 2019, p. 13. - 49.3 \% In June 2019. See: <http://www.trabajo.gob.ar/ downloads/estadisticas/Reporte_Laboral_Junio_2019.pdf>

65 SILVEIRA, Daniel \& ALVARENGA, Darlan, "Trabalho informal avança para 41,3\% da população ocupada e atinge nível recorde, diz IBGE". Report, 30 Augsut 2019, <https://g1.globo.com/ economia/noticia/2019/08/30/trabalho-informal-avanca-para-413percent-da-populacaoocupada-e-atinge-nivel-recorde-diz-ibge.ghtml>

66 ROSS SCHNEIDER, Ben and KARCHER, Sebastian Karcher. "Complementarities and continuities in the political economy of labour markets in Latin America". Socio-Economic Review. 2010, $\mathrm{n}^{\circ}$ 8, p. 623, 636.

67 COOK, Maria Lorena. The Politics of Labor Reform in Latin America. Between Flexibility and Rights. Pennsylvania: Penn State University Press, 2007, p. 45-46.

68 ROSS SCHNEIDER, Ben and KARCHER, Sebastian Karcher. Op. cit., p. 636.

69 Ídem, p. 640.

70 BENSUSÁN, Graciela. "Labour law, inclusive development and equality in Latin America". In: MARSHALL, Shelley Marshall and FENWICK, Colin (eds.). Labour regulation and development. Cheltenham: Edward Elgar, 2016, p. 175.

71 ILO. Labour Overview: Latin America and the Caribbean 12-19, 2016. 
- and the growth of formal workers in the labor market ${ }^{72}$. In this respect, the EU-MERCOSUR agreement may play an important role. Unlike other previous agreements, this one prescribes expressly that Parties should pay particular attention to, amongst other, "labor inspection in particular through effective implementation of relevant ILO standards on labor inspections labor" (Article 4). The EU has a particular interest because the reduction of informal workers could guarantee a relatively level playing field between the EU and MERCOSUR Member States. In this respect, the Domestic Advisory Groups and civil society actors, such as trade unions may also constitute key actors in putting pressure upon national governments in order to ensure the enforcement of national labor laws.

\section{CONCLUSION}

The FTA between the EU and MERCOSUR will have important legal consequences and will undoubtedly, if ratified, entail legal reforms. As it has been underlined, the EU regulatory power goes beyond the internal legal consequences that affect the EU Member States. This normative power triggers legal consequences in the relations with third countries or regional blocs, as it is the case of MERCOSUR. The EU can therefore be considered a true foreign policy actor, driven by self-declared normative principles that affect its global partners such as MERCOSUR. The deal reached between the EU and MERCOSUR announced on the occasion of the G20 Summit in Osaka in 2019 was a result of twenty years of negotiations. There are several steps ahead: the draft association agreement will have to be signed and ratified by the European Council, the European Parliament, MERCOSUR and national parliaments.

International trade is, as a matter of principle, a key element in achieving global food security, which is one of the key areas of the Agreement. This is due to the productive specialization of those countries with the necessary resources and abilities, which are capable of offering a greater quantity of production at competitive prices. This allows for greater global access and availability. However, there are still collateral damages and direct effects of the signing of agreements that affect the inequalities and food insecurity of the most disadvantaged population.

If the Agreement is ratified, the signing countries will be "forced" to adapt to new regulations and mechanisms. The UPOV91 agreement that privatizes the use of seeds in case of subsistence farming, and the reinforcement of mechanisms for the protection of abusive practices of international trade against the States, along with geographical indications, will shape the regulatory framework of these countries and will have effects on their citizens. Some of these additions will benefit the large producing and exporting companies, leaving aside most of the producers and communities that support food security in their countries. The pillars of cooperation and

72 BENSUSÁN, Graciela. Op.cit., p. 175. 
political dialogue emerge to reduce these uneven effects, but the texts have not yet been published.

MERCOSUR's external policy has traditionally addressed exclusively trade matters. In contrast, since the early 2000s, the EU external policy has included consistently labor standards on its FTAs. Unsurprisingly, the EU-MERCOSUR Agreement includes a Trade and Sustainable Development Chapter, which enshrines labor standards. Three types of measures are adopted in this Agreement to guarantee their protection and enforcement: firstly, substantive measures, which under the auspices of new agreements, guarantee the protection of the 1998 ILO Core Labor Standards: freedom of association, forced labor, child labor, and non-discrimination. It has also gone further and has included health and safety of workers, labor inspection, and discrimination against migrants. Secondly, procedural measures are adopted to ensure the implementation of such labor standards. Drawing upon a "promotional" approach, the amicable government consultations and the panel of experts is in charge of the interpretation of labor standards. However, unlike the US "conditional" approach, no trade sanctions can be imposed on the other party. This has reduced the confidence of civil society actors. Greater powers to private parties such as trade unions could improve this system. Thirdly, a governance dimension has been included in order to guarantee the participation of governments and civil society actors through formal channels in implementing labor standards. It has been argued that this could constitute a suitable avenue for civil society actors to influence and put pressure on the other Parties.

The final text of the Agreement remains to be seen. However, at this stage, it is possible to shape the MERCOSUR labor dimension in three ways: firstly, it may contribute to a better enforcement of the Socio-Labor Declaration, specifically through the reinforcement of the Socio-Labor Commission. Secondly, it can put pressure on Brazil, the biggest MERCOSUR player, to ratify ILO Convention 87. Thirdly, it can help MERCOSUR Member States reduce informal work.

The COVID-19 crisis and the challenges that globalization and interregional trade agreements may face in the aftermath of this period will shape the EU-MERCOSUR agreement and its final content. Therefore, its final impact upon food, security, and labor regulations remains to be seen.

\section{BIBLIOGRAPHIC REFERENCES}

"Crónica de un queso: su camino a ser denominación de origen y retos a enfrentar". Marcasur. 2019. Available at: <http://www.marcasur.com/ noticia. php?NoNold $=5021>$

BENDINI, Roberto. "The Future of the EU Trade Policy". Policy Department. European Parliament, 2015.

BENSUSÁN, Graciela. "Labour law, inclusive development and equality in 
Latin America". In: MARSHALL, Shelley Marshall and FENWICK, Colin (Eds.). Labour regulation and development. Cheltenham: Edward Elgar, 2016.

BRONCKERS, Marco and GRUNI, Giovanni. Taking the Enforcement of Labour Standards in the EU's Free Trade Agreements Seriously. 2019, vol 56, nº, p. 1591.

CAMPLING, Liam et al. "Working Beyond the Border? A New Research Agenda for the Evaluation of Labour Standards in EU Trade Agreements". International Labour Review. 2015.

CASTELLO, Alejandro. “Revisión y Actualización de la Declaración Sociolaboral del MERCOSUR". Derecho Laboral. 2015, n² 260.

CASTELLO, Eduardo, "Heterogeneidad y Fragmentación del Mercado de Trabajo (2010-2018)". Informe, 2019.

COOK, Maria Lorena. The Politics of Labor Reform in Latin America. Between Flexibility and Rights. Pennsylvania: Penn State University Press, 2007.

EBERT, Franz. "Labour provisions in EU trade agreements: What potential for channelling labour standards-related capacity building?". International Labour Review. 2016, vol 155, n³.

EUROPEAN COMMISSION. Annex 1, Legislation of the parties [online]. Brussels: s.n, 2019. Available at: <https://trade.ec.europa.eu/doclib/ docs/2019/september/tradoc_158330.pdf>

EUROPEAN COMMISSION. Bilateral safeguard measures [online]. Brussels: s.n, 2019. (Texts of the Trade Part of the EU-Mercosur Association Agreement). Available at: <https://trade.ec.europa.eu/doclib/docs/2019/july/ tradoc_158158.\%20Trade\%20Defense\%20-\%20Bilateral\%20Safeguards.pdf>

EUROPEAN COMMISSION. Documento estratégico regional 2007-2013 [Online]. Brussels: s.n, 2007. (Strategic Document European Commission). Available at: <http://eeas.europa.eu/archives/docs/mercosur/rsp/07_13_ es.pdf>

EUROPEAN COMMISSION. Intellectual Property Chapter [online]. Brussels: S.n, 2019. (Texts of the Trade Part of the EU-Mercosur Association Agreement). Available at: <https://trade.ec.europa.eu/doclib/docs/2019/september/ tradoc_158329.pdf>

EUROPEAN COMMISSION. Trade and Sustainable Development [online]. Brussels: s.n, 2019. Available at: <https://trade.ec.europa.eu/doclib/ docs/2019/july/tradoc_158166.\%20Trade\%20and\%20Sustainable\%20 Development.pdf>

EUROPEAN COMMISSION. Trade defense and global safeguards [online]. Brussels: s.n, 2019. Available at: <https://trade.ec.europa.eu/doclib/ docs/2019/july/tradoc_158157.\%20Trade\%20Defense\%20-\%20General\%20 
Principles\%20and\%20Global\%20Safeguards.pdf>

FAO. An Introduction to the Basic Concepts of Food Security [online]. EC FAO Food Security Programme, 2008. (Information Document). Available at: $<$ http://www.fao.org/3/a-al936e.pdf>

FERRAZ HAZAN, Bruno. "A incompatibilidade do modelo a partir da incorporação brasileira dos parâmetros da liberdade sindical". Revista de Direito \& Desenvolvimento da UniCatólica. 2019, vol 2, n 1, p. 39.

FRANCA FILHO, Toscano et al. "Protection of Fundamental Rights in Latin America FTAs and Mercosur: An Explanatory Agenda". European Law Journal. 2014, vol 20, n 6 .

FRANCA FILHO, Toscano. "External Relations". In: FRANCA FILHO, Toscano et al (eds.) The Law of MERCOSUR. Oxford: Hart Publishing, 2010.

GODINHO DELGADO, Mauricio. "Constitución de la República, Sistema Laboral Brasileño y Derecho Colectivo del Trabajo". Derecho Laboral. 2015, vol 57, n²59, p. 350.

GRAIN. El Convenio UPOV va contra principios de convivencia que hicieron posible el progreso de la agricultura. Available at: <https://www.grain.org/es/ article/entries/4640-el-convenio-upov-va-contra-principios-de-convivenciaque-hicieron-posible-el-progreso-de-la-agricultura>

GSTOHL, Sieglinde; HANF, Dominik. "The EU 's Post-Lisbon Free Trade Agreements: Commercial Interests in a Changing Constitutional Context". European Law Journal. 2014, vol 20, $n^{\circ} 6$.

HARRISON, James et al. "Labour Standards Provisions in EU Free Trade Agreements: Reflections on the European Commission's Reform Agenda". World Trade Review. 2019, vol 18, n 4.

HARRISON, James. "The Labour Rights Agenda in Free Trade Agreements". Journal of World Investment \& Trade. 2019, n²0.

HARRISON, James; BARBU, Mirela, CAMPLING, Liam; RICHARDSON, Ben, SMITH, Adrian. "Governing Labour Standards through Free Trade Agreements: Limits to the European Union's Trade and Sustainable Development Chapters". Journal of Common Market Studies. 2019, vol 57, n 2.

INTERREGIONAL FRAMEWORK COOPERATION AGREEMENT BETWEEN THE EUROPEAN COMMUNITY AND MERCOSUR, 15 Dec. 1995 - Joint Declaration on political dialogue between the European Union and Mercosur, IO L 69, 19 Mar. 1996.

LEAL-ARCAS, Rafael. "The European Union's Trade and Investment Policy after the Treaty of Lisbon". The Journal of World Investment and Trade. 2010, $n^{\circ} 11,463-514$. 
MANSUETI, Hugo. Derecho del Trabajo en el Mercosur. Buenos Aires: Ciudad Argentina,1999.

MERCED, Louie Dane C. "'Partners' for Change: Understanding the External Relations of ASEAN". Center for International Relations and Strategic Studies Commentaries. 2017, vol 4, $\mathrm{n}^{\circ} 20$.

MINISTERIO DE ASUNTOS EXTERIORES, UNIÓN EUROPEA Y COOPERACIÓN DE ESPAÑA. UPOV. Unión Internacional para la protección de las Obtenciones Vegetales. Available at: <http://www.exteriores.gob.es/ RepresentacionesPermanentes/OficinadelasNacionesUnidas/es/quees2/ Paginas/Convenios\%20y\%20otras\%20Organizaciones\%20Internacionales/ UPOV.aspx>

MUKHAMETDINOV, Mikhail. MERCOSUR and the European Union. Variation and Limits of Regional Integration. Cambrigde, MA: Palgrave Macmillan, 2019.

NOVITZ, Tonia. "In Search of a Coherent Social Policy: EU Import and Export of ILO Labour Standards?". In ORBIE, Jan and TORTELL, Lisa (Eds). The European Union and the Social Dimension of Globalization. London: Routledge, 2009.

PERULLI, Adalberto, "Fundamental Social Rights, Market Regulation and EU External Action". International Journal of Comparative Labour Law and Industrial Relations. 2014, vol 30, $\mathrm{n}^{\circ} 1$.

PUCHETA, Mauro. "Regional Integration and Labour Law: A Comparative Analysis of the EU and Mercosur". Orientador: Jeff Kenner. University of Nottingham. Nottingham 2019.

ROSS SCHNEIDER, Ben and KARCHER, Sebastian Karcher. "Complementarities and continuities in the political economy of labour markets in Latin America". Socio-Economic Review. 2010, n 8, p. 623-640.

SANAHUJA, Jose Antonio; RODRIGUEZ, Jorge Damián. Veinte años de negociaciones Unión Europea-Mercosur: Del interregionalismo a la crisis de la globalización. Fundación Carolina. 2019. Available at: <https://www. fundacioncarolina.es/wp-content/uploads/2019/09/DT_FC_13.pdf>

SICE. Acuerdo de Asociación Centroamérica-Unión Europea. Available at: <http://www.sice.oas.org/Trade/CACM_EU/Text_Sept14/Index_s.as>

SILVEIRA, Daniel \& ALVARENGA, Darlan. "Trabalho informal avança para $41,3 \%$ da população ocupada e atinge nível recorde, diz IBGE". Report, 30 August 2019 <https://g1.globo.com/economia/noticia/2019/08/30/ trabalho-informal-avanca-para-413percent-da-populacao-ocupada-e-atingenivel-recorde-diz-ibge.ghtml>

TIMINI, Jacopo et al."The EU-Mercosur Free Trade Agreement: Main Features and Economic Impact". Economic Bulletin, 2020. 
UNITED NATIONS. El aumento de la desigualdad, el rostro de la globalización. Available at: <https://news.un.org/es/story/2018/05/1433082>

UNITED NATIONS. Goal 2: Zero Hunger. Available at: <https://www.un.org/ sustainabledevelopment/hunger/>

VAN DE PUTTE, Lore and ORBIE, Jan. "EU Bilateral Trade Agreements and the Surprising Rise of Labour Provisions". International Journal of Comparative Labour Law and Industrial Relations. 2015, vol 31, n 3.

\section{$\sim \sim$ 米 $\sim$ \\ Medidas de segurança alimentar e regulamentação trabalhista no Acordo UE-MERCOSUL: uma visão geral dos desafios legais}

Resumo: Em junho de 2019, a União Europeia e o MERCOSUL concordaram em assinar um amplo acordo de livre comércio (TLC). Seu objetivo é aumentar o comércio inter-regional e desenvolver a cooperação em áreas não comerciais, como segurança alimentar e regulamentação trabalhista. A UE tem um poder regulador através do qual aspira exportar seus valores e padrões para o resto do planeta. Portanto, após a ratificação deste acordo, o MERCOSUL e, portanto, seus Estados membros serão forçados a reformar seus sistemas legais. A segurança alimentar pode levar os Estados membros do MERCOSUL a se alinharem com certos regulamentos internacionais, como a União Internacional para a Proteção de Novas Variedades de Plantas (UPOV). Também pode afetar as regulamentações relacionadas à propriedade intelectual. Os regulamentos trabalhistas constituem outro aspecto essencial dos interesses não comerciais deste acordo. Para evitar o dumping social, a UE pode exigir que os Estados membros do MERCOSUL ratifiquem certas convenções da OIT, como a 87 - que ainda não foi ratificada pelo Brasil para garantir condições equitativas. Como o texto final está atualmente em negociação, o impacto deste acordo dependerá em grande parte da vontade política das partes.

Palavras-chave: União Europeia, MERCOSUL, segurança alimentar, regulamentação trabalhista, Acordo de Livre Comércio (ALC).

\section{BIOGRAPHIC SUMMARY}

Mauro Pucheta is a Lecturer in Law at Kingston University London. He holds a law degree (Universidad Nacional de Córdoba, Argentina) and a master's degree in Labor Law (Université Paris 1-Sorbonne). He also has a PhD in Law (University of Nottingham). 
César Álvarez Alonso is Adjunct Professor of Public International Law at IE University. He holds a PhD in Legal and Political Sciences (Universidad Pablo de Olavide). He has been a Visiting Researcher at the Institute for Global Law and Policy and Vice-President of the Harvard European Law Association at Harvard Law School.

Carlos Ruiz is holds a BA in Business Administration and Commerce and a master's degree in Strategies and Technologies for International Cooperation and Development (Universidad Politécnica y Universidad Complutense de Madrid). He currently supports the Technical Cooperation Directorate from the Inter-American Institute for Cooperation on Agriculture (IICA). 